\title{
Iranian EFL teachers' major personality types and teaching attitudes
}

Ghorbani, Saeed $₫$

English Department, Imam Reza International University, Iran (Saeed.ghorbani90@gmail.com)

Akbari, Omid

English Department, Imam Reza International University, Iran (omidakbari@imamreza.ac.ir)

Ghonsooly, Behzad

Department of English Language and Literature,Ferdowsi University of Mashhad, Iran (ghonsooly@um.ac.ir)

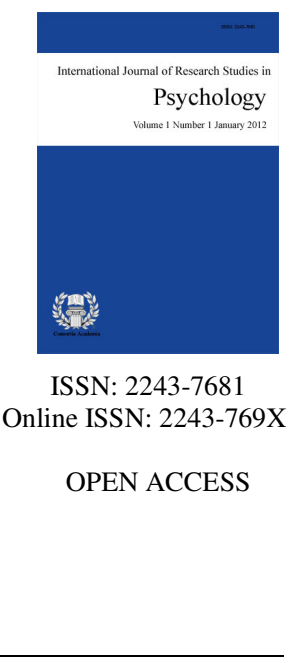

Received: 22 December 2014

Revised: 29 January 2015

Accepted: 4 February 2015

Available Online: 22 February 2015 DOI: $10.5861 /$ ijrsp.2015.1036

\begin{abstract}
Research on teachers' characteristics has been underway for over a century. In continuation of these studies, the present research study strived to explore Iranian EFL teachers' major personality and attitude. Discovering the major personality types and teaching attitudes among Iranian EFL teachers, therefore, was the primary purpose of this study. Reviewing the related literature and becoming informed about other researchers' findings in this area, personality types and teaching attitudes of Iranian EFL teachers were measured by using Myers-Briggs Type Indicator (MBTI) and Foreign Language Teacher Beliefs Questionnaire. For this purpose, 79 English teachers teaching in 24 foreign language institutes in Mashhad, Iran's northeast were chosen as the participants of this study. Distributing the two instruments among EFL teachers and analyzing the obtained data by means of SPSS software revealed that that ISTP and ISTJ are the most frequent personality types among Iranian EFL teachers and classroom management got the highest score among three subareas of teaching attitude scale. Study's implications, applications, and suggestions for further research were all presented at the end.
\end{abstract}

Keywords: personality type; teaching attitude; EFL; teacher; Iran 


\section{Iranian EFL teachers' major personality types and teaching attitudes}

\section{Introduction}

The field of Applied Linguistics has got many branches and is relevant to many activities of our lives. In his trying to make the scope of applied linguistics more clear and understandable, Cook (2003) provided three underlying areas for this academic discipline. According to him, second and foreign language education is one of the sub parts of the first area which is language and education. So teaching and learning a new language is one of the subparts of Applied Linguistics and lots of issues regarding these two have been investigated by many scholars of this field throughout the history. In other words, researchers interested in the issues related to language learning and teaching have scrutinized second and foreign language learning and teaching and their related issues from different angles. Some researchers are more interested in language learners while others are more oriented toward issues related to the teacher of a second or foreign language. Here, this research is more oriented toward language teaching rather than language learning; therefore, some of the factors affecting language teaching are dealt with. The researcher of the present study believes that having more information and being more aware of the qualities and favorites of language teachers will guide us in our planning for creating more appropriate teacher training programs.

Harkin and Turner (1997) believed that teaching is a complex activity that is influenced by, among other things, teachers' personality, characteristics, and teachers' beliefs in their ability to affect students' outcomes. This subarea of applied linguistics, as mentioned by Cook (2003), and the effective factors on it has been one of the popular areas of enquiry by organizations and journals concerned with the discipline. There are many factors, discovered by researchers, which affect a successful foreign or second language education or at least have some kind of relationship with it. To the researcher's best knowledge, the issues of personality and attitude have not been much paid attention to, particularly in Iran's context. Therefore, here, this research is going to deal with the personality and attitude as two important factors existing in every language teacher. In general, discovering about Iranian EFL teachers' attitude and personality is the primary goal of this study.

\section{Literature review}

\subsection{Teacher Personality}

Personality is one of the main and significant themes in the field of psychology. Williams and Burden (1999, as cited in Larenas, Moran, \& Rivera, 2011) referred to personality as an individual's characteristic patterns of thought, combination of behavior and emotion with mechanisms of psychology behind those patterns. Longman dictionary of language teaching and applied linguistics defines personality as follows: "Those aspects of an individual's behavior, attitudes, beliefs, thought, actions and feelings which are seen as typical and distinctive of that person and recognized as such by that person and others. Personality factors such as self-esteem, inhibition, anxiety, risk taking and extroversion, are thought to influence second language learning because they can contribute to motivation and the choice of learner strategies" (Richards \& Schmidt, 2002, p. 394-395). According to Pervin and John (2001), "personality is the part of the field of psychology that most considers people in their entirety as individuals and as complex beings" (as cited in Dornyei, 2005, p. 10). "The personality is the totality of character and behavioral traits peculiar to an individual. No two persons are alike in this respect, not even identical twins" (Cruickshank, Jenkins, \& Metcalf, 2003, p. 5).

Dornyei (2005) believed that personality variables are important factors both in revealing humans' behavior and in learning and academic achievement. According to this idea, personality can be considered as an important and determining factor in language learning and teaching. This idea is endorsed by lots of academic research 
projects that have ever been published on the issue of personality and language education. Callahan (1966, as cited in Tope, 2011, p. 7) believes that "personality may be viewed as dynamic organization of those traits and characteristic patterns of behavior that are unique to the individual".

Studies conducted by Elias and Steward (1991) and also study of Foster and Hornet (1988) showed that personality types can explain how teachers teach and how students learn. Many researchers have ever worked on the issue of personality both in the area of learning and in the area of teaching. In the area of personality and language learning, for example, Pritchard (1952) and Chastain (1975) were the researchers who tried to find the most effective personality type in language learning. Although the results of these works were contradictory, the high number of works done by salient figures on personality shows the importance and popularity of this issue among them.

Personality of a teacher was also considered as an important factor in arranging the conditions of learners' environment for having an effective learning. In his research study, Dodge (1948) compared the personality traits of two groups of successful teachers. The first group of teachers was asked to fill out a personality questionnaire. Dodge (1948), then, categorized the items which had more similarity with each other. So five categories (traits) of successful teachers were produced as a result of that categorization: "(1) social or at ease in social contacts, more frequently than did the less successful teachers; (2) more willing to take initiative and assume responsibility (3) free from fears and worries; (4) sensitive to and valuing the opinions of others; (5) slow in making decisions" (p. 107). Conducting this research on the second group of teachers to discover their personality traits made it clear that the same traits are the characteristics of the second group although disagreements were indicated on a number of individual inventory items. In other words in both groups the more successful teachers reported themselves as possessing the abovementioned traits more frequently than did the less successful instructors.

Based on Murray (1972, as cited in Tope, 2011), personality affects teachers' behaviors in many ways, such as their interaction with students, methods to be used, and learning experiences chosen. According to Callahan (1966, as cited in Tope, 2011), a teacher personality which creates a learning environment in which learners feel comfortable and motivated to learn is said to have desirable teaching personality. Using Cattell's 16 personality factor tests, Lamke (1951) tried to explore the personality of good and poor teachers. According to the finding section of this study, some of the features of good and poor teachers are as follows: Good teachers are more gregarious, frivolous, and adventurous, have strongly artistic or sentimental interests, and cool than poor teachers. Poor teachers are shyer, cautious, and conscientious than good teachers. In a research study conducted by Macdaid, McCaulley, and Kainz (1986, as cited in Alibakhshi, 2011) the personality of 804 American teachers was investigated. According to this study, $49.50 \%$ had a combined preference for sensing and judgment. The second most favored combination among this group of American teachers was sensing and feeling $40.80 \%$. The largest percentage of the 16 MBTI types was the ISFJ (17.91\%).

In a research conducted by Lawrence (1997), individual types of 5362 American teachers were investigated. According to this research study, it was found that the most frequently "preferred typology" was ESFJ teacher (as cited in Alibakhshi, 2011). Blaskova, Blasko, Jankalova, and Jankal (2014) conducted a research study on key competences of personality among university teachers. After doing 3 consecutive focus group interviews with university teachers 10 personality competences were introduced by them as appropriate and good personality competences. Those 10 personality competences are as follows: Morally and ethically acting personality, professional personality, personality with valuable scientific effort, acclaimed author and honest personality, personality with excellent teaching competences, personality acting as a role model, mature personality, critically thinking personality, sophisticated and communicating personality, and always motivating personality.

The issue of teachers' personality was also taken into account alongside with other factors. For instance, in a study carried out by Caroline Grace (1998) at the University of Purdue, personality was taken into consideration 
alongside with tolerance of ambiguity and vocabulary retention in computer assisted language learning. She concluded that learners with different types of personalities, obtained through MBTI, can learn many words if the verification of the meaning of words is presented in first language and this retention of vocabulary is regardless of their tolerance for ambiguity. Erton (2010) tried to find the relation between personality traits, language learning styles, and success in foreign language achievement. At the end of his research, Erton concluded that "there is no significant statistical relationship between personality traits" (p. 124), and extroverts and introverts had a tendency to employ different learning styles and finally, "there is not a strong but low statistical relationship between the personality traits and the learning styles" (Erton, 2010, p. 124).

Larenas, Moran, and Rivera (2011) compared teaching styles and personality types of EFL instructors in public and private sectors. In this exploratory study which was conducted on 15 teachers in private sectors and 15 teachers in public sectors, it was revealed that public sector teachers are extroverted and private sector teachers are introverted. The researchers also mentioned that in this study gender had got no effect on personality of EFL teachers. In on the Impacts of Gender and Personality Types on Iranian EFL Teachers' Teaching Efficacy and Teaching Activities Preferences, Alibakhshi (2011), employing MBTI, found that 43.21 percent of Iranian EFL teachers have ESTJ personality and 29.28 percent of them have ISTJ personality type and 14 other personality types were seen in about 30 percent of the participants. He concluded that "there is no significant difference between teachers with different personality types in terms of their teaching efficacy. That is teachers with ESTF, ISTJ, and other personality types have the same sense of teaching efficacy. The results also indicate that the difference between male and female teachers' teaching scores is not significant (p. 12)". According to this study, it could be said that personality and gender of Iranian EFL teachers do not influence their beliefs about their abilities in teaching. Regarding the impact of gender and personality on teaching activities, the results show that personality and gender have significant impacts on the teaching activities preferences. Pishgadam and Sahebjam (2012) and also Behnam and Bayazidi (2013) were other Iranian researchers who paid attention to this variable in relation to other factors.

\subsection{Teacher Attitude}

Attitude has been defined in many different ways. Allport's (1935) definition of attitude which was offered many years ago is the most frequently quoted definition of attitude. He defined attitude as "a mental and neutral state of readiness, which influences the individual's response to all objects and situations with which it is related" (as cited in Azizinezhad, Hashemi, \& Darvishi, 2012, p. 134). From Triandis (1971, p. 2) point of view, an attitude is "an idea charged with emotion which predisposes a class of actions to particular class of social situations." Attitude is also defined as "a hypothetical construct used to explain the direction and persistence of human behavior" (Baker, 1992, as cited in Lee, 2009, p.13). Attitude is divided into three components (Rosenberg \& Hovland, 1960, as cited in Azizinezhad et al., 2012): Cognitive, affective, and behavioral. Attitudes and beliefs are important and influential factors in doing all jobs, so teaching is not an exception. In fact, teaching in any discipline is strongly influenced by the attitudes of those who teach that discipline.

Williams and Burden (1997), "argued that teachers are highly influenced by their beliefs" (as cited in Dogruer, Menvis, \& Eyyam, 2010, p. 84). "From both psychological and educational perspectives, beliefs are usually described as propositions of mind that determines individuals' behaviors" (Pajares, 1992, as cited in Debreli, 2011, p. 61). Zheng (2009) explored the definitions ever presented for teachers' beliefs. According to him, there are different definitions for the concept of teachers' beliefs the examination of which provides one with some common features for this concept. These feature are as follows: 1) "belief is a subset of a group of constructs that name, define, and describe the structure and content of mental states that are thought to drive a persons' actions" (p. 74). 2) beliefs have the capability of influencing both teachers' professional development and classroom practices 3) "one of the greatest confusions about beliefs comes from its relationship to knowledge. In literature, knowledge is either taken as different from beliefs by nature or used as a grouping term without distinguishing between what we know and what we believe (p. 74)". 
According to Gursoy (2013), teachers' attitude can also impact motivation of the learners. So it is important for an EFL teacher to have positive attitudes toward the English language and to reflect this positivity in his or her classroom. Also, Dornyei (1998) and Dornyei and Csizer (2002) referred to the importance of this issue in language learning and concluded that having positive attitudes toward a language facilitates its learning while maintaining negative attitudes acts as psychological barrier against the learning of that foreign language (as cited in Rahimi \& Hassani, 2012). This opinion was confirmed both in Iran by Rahimi and Hassani (2012) and abroad by Nikolov (2001). Nikolov (2001), for example, found students' negative attitudes toward Russia or Russian people were responsible for their failure to learn the language. The researcher believes the same claim can be transferred to the area of foreign language teaching. Therefore, he believes if the foreign language teachers take positive attitudes about their teaching and about their career, this positivity of their attitudes and thinking will lead them to a professional success. For this reason, many researchers (Liao, 2007; Lee, 2009; Karavas \& Drossou, 2010; Gursoy, 2013) have tried to explore the issue of teachers' attitudes since it is believed that by getting familiar with the attitudes of EFL teachers, one will be more successful to meet the needs of this group of people.

Observation, interview, and questionnaire are common ways of discovering teachers' attitudes. In conducting this research, the researcher preferred to use a questionnaire for taking the attitudes of EFL teachers out. In the field of second or foreign language, attitudes toward language teaching and learning have been investigated by many researchers (e.g.: Lafaya \& Tsuda, 2002; Walker, Shafer, \& Iiams, 2004; Rahimi \& Hassani, 2012; Azizinezhad et al., 2012; Gursoy, 2013). Learners' attitudes toward foreign language learning seem to be a widely researched topic. However, the study on foreign language teachers' attitudes deserves much more attention as its results will pave the way of being more aware about current mentality of EFL teachers. Understanding teachers' specific attitudes about English teaching can inform researchers and teacher trainers about how teachers are likely to do their job, and how to provide useful teacher education courses. The current survey, therefore, is an attempt to contribute to the present research literature on English teachers' attitudes by investigating EFL teachers' attitudes toward English language teaching.

The issue of teachers' attitudes and beliefs have been researched and investigated in different ways. According to "Psychology for Language Teachers" written by Williams and Burden in 1997 teachers are highly affected by their beliefs. They also stated that teachers' beliefs are divided into three groups: 1) beliefs about learners 2) beliefs about learning and 3) beliefs about themselves. Walker et al. (2004) conducted a research study in which attitudes of English language teachers about English language learners were the main focus. Based on the finding of this study, the general nature of teacher attitudes on English language learners seem to be neutral to strongly negative. It was also found that only 18 percent of teachers believed that English language learners have academically performed well.

In a research conducted in Taiwan's context, Liao (2007) tried to discover the English teachers' beliefs about teaching English to elementary school children. For this purpose, the researcher developed a questionnaire which measured the beliefs of English teachers in three areas namely as: The nature of children's English development, English teaching methods and techniques employed in the classroom, and a strong sense of self efficacy as English teachers. This questionnaire also had an open ended question at the end which asked the respondents to write the necessary qualifications of a successful English teacher in an elementary classroom. Regarding the multiple questions, the participants who had been divided into two groups of pre service and in service teachers showed significance difference in only three items of the questionnaire and a general agreement was found on most of the items.

About the open ended question, however, the responses were categorized into 5 main qualification categories for a successful English teacher. Based on these responses, the necessary qualifications of a successful English teacher originates from his or her English proficiency, his or her personality, teaching skills, student-centered concerns, and physical readiness. Finally, Liao came to this conclusion that beliefs of a teacher is based on his earlier learning experiences, teacher training courses taken at school, and his cultural background. 
The results section of the study also revealed that elementary school English teachers of Taiwan, both in service and pre service ones, have a similar set of beliefs in common. From their open ended responses, successful elementary school English teachers are generally thought to have such main characteristics as a pleasant personality and an optimistic attitude towards teaching, ability to effectively use various classroom teaching and management skills, and a good command of the English language (Liao, 2007).

In a very nice study conducted by Karavas and Drossou (2010), the issue of change in teachers' beliefs was investigated. Karavas and Drossou surveyed a group of EFL student teachers before and after their teaching practice. When the participants were asked about some issues such as pair or group work, promoting cooperation and interaction, and encouraging independence before and after their teaching practice, it was revealed that no significant change has happened in the beliefs and attitudes of this group of participants as a result of teaching practice. These findings challenged teacher education courses. According to this study, "it seems that even if student teachers' beliefs converge during their teacher education courses, they tended to diverge after their teaching practice experience thus suggesting that pre-service teacher education programs are ineffective in changing or influencing student teacher beliefs" (Karavas \& Drossou, 2010, p. 263).

Of course some beliefs on error correction and teacher as transmitter of knowledge had become solidified and more widespread among these EFL teachers. In another research study conducted by Thomas (2013), the beliefs of Pakistani qualified and unqualified teachers were explored. 123 teachers chosen from 15 Pakistani schools were divided into two groups of qualified and unqualified teachers. The data gathered for this paper revealed that there is no significant difference in the beliefs of professionally qualified and professionally unqualified teachers about education and teaching approaches. Finally Thomas (2013) concluded that both groups of teachers believe student-centered methods are more influential than the other methods for developing higher order skills among students. The effect of a teacher's beliefs on other issues was also taken into consideration. Chacon (2005), for example, believed that a teacher's way of understanding and organizing instruction is affected by his beliefs, perceptions, and assumptions about teaching and teacher efficacy.

Doğruer et al. (2010) distributed a questionnaire among 35 English teachers. The researchers found out that as far as beliefs about language learning is concerned, the most important factor for the participants is language aptitude of learners and when it comes to teaching styles the participants preferred to use individual activities. Rahimi and Hassani (2012) worked on the attitudes of 244 Iranian high school students about English learning and also English textbooks. Based on this study, students' general evaluation of English materials showed that they have negative perceptions to their textbooks. It was also become clear that Iranian high school students have positive attitudes toward learning English in general.

Azizinezhad et al. (2012) carried out a study in which teachers' attitude was a main variable. He and his colleagues tried to understand about the attitudes and teaching techniques of Iranian EFL teachers in small and large classes. Finally, they concluded that regardless of teachers' gender, being expert or novice, and education degree all teachers used more teaching techniques in small classes than large classes. It was also revealed that there was not any significant difference between the attitudes of novice or non-professional and experienced or professional teachers in using teaching techniques in their different class sizes. "Further data analysis more specifically those of the interview also showed that in each context, teachers had interesting attitudes as: Female and male teachers' attitudes were not the same in small classes in a sense that female teachers tended to use more teaching techniques than their male counterparts" (p. 136). In a much more recent research on this variable, Gursoy (2013) obtained the attitudes of prospective ELT teachers towards English language. In this study, it was revealed that all the participants had mildly positive attitudes towards English but among them the female participants' attitudes were more positive than men.

As it was seen above, a number of researchers have ever dealt with the personalities and attitudes of English teachers both inside and outside of Iran. They have investigated these two variables in different aspects and by different instruments but none of them have ever examined attitude and personality alongside each other in a 
single research study particularly in an Iranian context. The present study, therefore, tried to fill this gap and it also tried to explore the major personality type and teaching attitude of Iranian EFL teachers alongside each other which is the first study of its kind in Iran, to the researcher's best knowledge.

\subsection{Purpose and Significance of the Study}

Personality type and teaching attitude of all EFL teachers are not the same. Taking this issue into account persuaded the researcher to explore these variables among Iranian EFL teachers and also posed this question that whether one can introduce a specific teaching belief or personality type as the dominant one or not. In the area of second or foreign language teaching many scholars have ever tried to investigate many factors related to or affecting teachers' performance. So, each of these researchers, based on their interests, abilities, and guesses, has tried to discover an influential factor among EFL teachers. The researcher believes some factors such as personality and attitude can be effective on or in relationship with better performance of the teacher, so the main purpose of the present study is to investigates the major personality types and teaching attitudes of Iranian EFL teachers teaching in Mashhad, Iran's northeast. To the researcher's best knowledge, such a topic has less been researched in Iran's context. In this perspective, therefore, the present study gains significance as the results can shed more lights on the issue of personality types and teaching attitudes of all EFL teachers in general and Iranian English teachers in particular which may be useful for other researchers or practitioners of the field. This study is also significant since its focus is on English language teachers only and it ignores teachers of other disciplines.

\subsection{Research Questions}

Considering the abovementioned objectives, this study sought answers to the following questions:

$>\quad$ What are the major personality types among Iranian EFL teachers?

$>\quad$ What are the major teaching attitudes among Iranian EFL teachers?

\section{Methodology}

\subsection{Participants}

Participants of this study included English language teachers of different foreign language institutes in Mashhad, a city in Iran's north east. They consisted of 79 English teachers who were all teaching at intermediate or upper intermediate levels. There were both (N: 38, 48.10\%) female and (N: 41, 51.89\%) male EFL teachers. The members of this group were between 22 and 43 with a mean of 27.24. They were different in terms of social, economic, and educational backgrounds and were all university students or university graduates of different colleges and universities. Most of them were majoring or majored in four fields of English teaching, English translation, English literature, and Linguistics and only 10 of them had a major not related to English. These irrelevant majors were: Accounting, history, physics, political sciences, psychology, urban planning and design, biology, Persian literature, and Alimentation. These participants were holders of BA (N: 56, 70.88\%) and MA (N: 23, 29.11\%). All of these teachers were teaching at 24 foreign language institutes in Mashhad. Some of these language institutes are: Aftab, Beh Ayin, Golestan, Khayam, Kish Air, Kish Mehr, Mahan, Paraks, etc. It is worth mentioning that this research's sampling was based on convenience or opportunity sampling. The criteria of this sampling are accessibility and availability (Dornyei, 2007).

\subsection{Instrumentation}

Two instruments were used in this research study, "Foreign Language Teacher Beliefs Questionnaire", and "Myers-Briggs Type Indicator (MBTI)". 
Ghorbani, S., Akbari, O., \& Ghonsooly, B.

Foreign Language Teacher Beliefs Questionnaire - Foreign Language Teacher Beliefs Questionnaire was developed by Nicole Mills at Harvard University in 2013. She adapted this questionnaire from previously constructed Teachers' Sense of Efficacy Scale designed, developed, and validated at Ohio State University by Megan Tschannen-Moran, and Anita Woolfolk Hoy in 2001. Because this questionnaire was developed at Ohio University it is sometimes called the Ohio State Teacher Efficacy Scale. Foreign Language Teacher Beliefs Questionnaire contains 23 items in which each item is asking teachers' opinion on a specific teaching task and is followed by a five-point Likert scale ranging from not well to exceptionally well. This questionnaire measures foreign language teachers' attitudes on teaching a foreign language and it provides one with three factors including: Attitudes on student engagement, attitudes on instructional strategies, and attitudes on classroom management.

This questionnaire was also used by Mills (2013) in a qualitative research, Action Research: Bridging Theory and Practice, at Harvard University. It is worth mentioning that there are some other ways of eliciting teachers' attitudes and beliefs. Observation, for instance, can be a good way of discovering one's attitudes but it may not show all kinds of person's attitudes and beliefs that we want to discover. This disadvantage of observation is in addition to its time consuming nature. Regarding the use of interview the researcher agrees with Borg (2006, as cited in Debreli, 2011) that says some beliefs of teachers are emotional so they cannot be elicited by an interview. In other words, the interview is not able to take the feelings of the teachers out. For the above reasons, the researcher used a questionnaire to obtain this concept among Iranian EFL teachers.

Myers-Briggs Type Indicator (MBTI) - Myers-Briggs Type Indicator (MBTI) is the second instrument of this study. In 1976, Isabel Myers and Katharine Briggs who where a mother and daughter team added another dichotomy to those of Carl Jung and that was Judging-perceiving. In other words, adding judging-perceiving dichotomy to the Jung's taxonomy was the main difference between Myers and Briggs' work and that of Jung. This new version of personality inventory, known as MBTI, is now the most widely employed personality test in the world and has ever been translated into 16 languages (Dornyei, 2005). The use of the word indicator instead of the common term of test or inventory is not accidental. "It is related to the fact that the dimensions of MBTI do not refer to traditional scales ranging from positive to negative. Rather, they indicate various aspects of one's psychological set-up" (Dornyei, 2005, p. 19).

For gaining the personality types of EFL teachers the translated version of MBTI, a self-report questionnaire, was used. This version of MBTI was prepared specifically for Iran's culture and context and it was validated by the Iranian institute of Azmoonyar Puya (2009). Each item of the questionnaire contains two options from which teachers were supposed to choose one. The index of validity was over 0.80 and all the items had positive significant correlation with the whole test. According to R.M. Felder, G.N. Felder, and E. J. Dietz (2002, p. 2-3) "The Myers-Briggs Type Indicator measures preferences on four scales derived from Jung's Theory of Psychological Types". They provide the four dichotomies as follows:

$>$ Introversion (interest flowing mainly to the inner world of concepts and ideas) / Extraversion (interest flowing mainly to the outer world of actions, objects, and persons),

$>$ Sensing (tending to perceive immediate, real, practical facts of experience and life) / Intuition (tending to perceive possibilities, relationships, and meanings of experiences),

> Thinking (tending to make judgments or decisions objectively and impersonally) / Feeling (tending to make judgments subjectively and personally),

$>$ Judging (tending to live in a planned and decisive way) / Perceiving (tending to live in a spontaneous and flexible way).

The MBTI requires the participants to decide on one segment of each dichotomy. The permutation of the preferences produces 16 types of combinations which is usually marked by the initial letters of each preference 
(since two words start with an "I" intuition is marked with the letter "N"). These 16 possible personality types are as follows: ISTJ, ISFJ, ISTP, ISFP, ESTP, ESFP, ESTJ, ESFJ, INFJ, INTJ, INFP, INTP, ENFP, ENTP, ENFJ, and ENTJ. "The 16 MBTI types have been found to be remarkably valid because, as Ehrman (1996) explained, the combinations are more than sum of the parts: They outline real, recognizable character types and thus the inventory has proved to be useful in a wide variety of contexts" (Dornyei, 2005, p. 20). Pedagogy, career counseling, team building, group dynamics, family business, leadership training, marketing, marriage counseling are some of the areas in which MBTI is used. A person's type is expressed as one of sixteen possible combinations of these preferences. For instance, an ENTP would have a preference for extraversion, intuition, thinking, and perception.

\subsection{Data Collection and Analysis}

The process of data collection started in July and ended in September, 2014. This study was undertaken in 24 foreign language institutes in Mashhad, Iran's northeast. The MBTI and Foreign Language Teacher Beliefs Questionnaire were distributed among EFL teachers. Most members of participants were the researcher's friends, thus they took part in the study intimately and voluntarily. The researcher was present during the administration to offer clarifications on the probable misunderstandings on the part of teachers. Researcher's availability was necessary because his presence and explanations solved many problems and misunderstandings with which teachers had encountered. In order to attain a reliable and valid evaluation, the purpose and confidentiality of the study were also explained. Moreover, the researcher tried to make connections with the developers of the questionnaires in order to get their viewpoints on the right way of data collection. In this regard, the researcher had the opportunity of making some connections with Nicole Mills who is the coordinator of French language at Harvard University and the developer of the Foreign Language Teacher Beliefs Questionnaire.

After distributing, in foreign language institutes, the two questionnaires among the EFL teachers and collecting the required data, major personality types and teaching attitudes were attained employing descriptive statistics. All the statistical analysis of the study was done using SPSS version 18. For the purpose of making a deeper understanding on the part of readers, the results of all statistical procedures have been presented in clear tables and figures.

\section{Results}

\subsection{Descriptive Statistics}

In this segment, descriptive examination of the research's variables is dealt with. Based on Table 1, only 13 types of personality, out of 16 possible types, were seen among the participants of the study who were Iranian teachers of English. This table shows that most Iranian EFL teachers (22.8\%) have ISTP and ISTJ as their personality type while other types of personality are all lower than 9 percent. The percentage and the frequency of each obtained personality type can be seen in Table 1.

It is worth mentioning that ENTP, ISFJ, and ESFJ are three personality types which were absent among these 79 English teachers. In Table 2, the descriptive statistics for each of the underlying parts of teaching attitude questionnaire are presented. These descriptive criteria are: Minimum, maximum, mean, and standard deviation. According to the Table 2, the mean scores for each of the three subparts of student engagement, instructional strategies, and classroom management are 3.903, 3.973, and 4.002, respectively. Therefore, it can be said that classroom management are more dominant in comparison with the other two areas. In other words, it was this area, classroom management, which gained the highest score when Iranian EFL teachers were making judgments about their own teaching performance. 
Ghorbani, S., Akbari, O., \& Ghonsooly, B.

Table 1

Descriptive Statistics for Personality Types

\begin{tabular}{lcc}
\hline & $\mathrm{f}$ & $\mathrm{P}$ \\
\hline ISTP & 18 & 22.8 \\
ISTJ & 18 & 22.8 \\
ENFJ & 4 & 5.1 \\
INTP & 7 & 8.9 \\
ESFP & 3 & 3.8 \\
ESTJ & 5 & 6.3 \\
INTJ & 6 & 7.6 \\
ENTJ & 3 & 3.8 \\
INFJ & 3 & 3.8 \\
ISFP & 4 & 5.1 \\
INFP & 2 & 2.5 \\
ESTP & 5 & 6.3 \\
ENFP & 1 & 1.3 \\
Total & & \\
\hline
\end{tabular}

Table 2

Descriptive Statistics of Teaching Attitudes Subparts

\begin{tabular}{llcccc}
\hline \multicolumn{1}{c}{ Variables } & $\mathrm{N}$ & Minimum & Maximum & Mean & Std. Deviation \\
\hline Student Engagement & 79 & 2.70 & 5.00 & 3.903 & .52 \\
Instructional Strategies & 79 & 2.80 & 5.00 & 3.973 & .57 \\
Classroom Management & 79 & 2.30 & 5.00 & 4.002 & .65 \\
\hline
\end{tabular}

\section{Discussion and Conclusion}

The present research study tried to explore personality types and teaching attitudes of Iranian EFL teachers. To the researchers' best knowledge, few researchers have ever conducted a study investigating these variables in a single study. Discovering major personality types and teaching attitudes of Iranian English teachers were the main purpose of this research study. After distributing instruments among English teacher at intermediate and upper intermediate levels in foreign language institutes and analyzing the obtained data by means of SPSS software, it was revealed that ISTP and ISTJ are equally the most frequent personality types among Iranian EFL teachers teaching in Mashhad. In fact, it was found that being tolerant and flexible and also quite and serious are main characteristics of this group of EFL teachers. Among the three underlying areas of teaching attitude questionnaire classroom management received the highest score and instructional strategies and student engagement got the second and the third place respectively.

Many researchers have ever devoted much of their time on teachers' qualities. In a research study conducted by Macdaid et al. (1986, as cited in Alibakhshi, 2011) the personality of 804 American teachers was investigated. According to this study, $49.50 \%$ had a combined preference for sensing and judgment. The second most favored combination among this group of American teachers was sensing and feeling $40.80 \%$. The largest percentage of the 16 MBTI types was the ISFJ (17.91\%). In another research conducted by Lawrence in 1997, individual types of 5362 American teachers were investigated. According to this research study, it was found that the most frequently "preferred typology" was the extraverted- sensing-feeling-judging (ESFJ) teacher (as cited in Alibakhshi, 2011).

In the present research study, however, only 13 personality types were identified out of the possible 16 . As mentioned above, ISTP and ISTJ are the most frequent personality types of EFL teachers in Mashhad which is not the same as abovementioned researches' results. In the research projects conducted in Iran, the result was more similar, however. For instance, Alibakhshi (2011), employing MBTI, found that 43.21 percent of Iranian EFL teachers have ESTJ personality and 29.28 percent of them have ISTJ personality type and 14 other 
personality types were seen in about 30 percent of the participants. Similar to the present research, Alibakhshi's (2011) study also recognized ISTJ as one of the most frequent personality types. Similar to, Alibakhshi (2011), Behnam and Bayazidi (2013) found ESTJ as the most frequent type of personality among Iranian English teachers.

Attitudes of English teachers have also been researched by language researchers. Observation, interview, writing composition, and questionnaire have all been used as the proper ways of eliciting a teacher's attitudes. Debreli (2011) used diaries as a new way of discovering beliefs and attitudes of English teachers. Azizinezhad and his colleagues (2012), using a questionnaire and an interview, conducted a research study in which teachers' attitude was a main variable. Azizinezhad et al. (2012) revealed that there was not any significant difference between the attitudes of novice or non-professional and experienced or professional teachers in using teaching techniques in their different class sizes. "Further data analysis more specifically those of the interview also showed that in each context, teachers had interesting attitudes as: Female and male teachers' attitudes were not the same in small classes in a sense that female teachers tended to use more teaching techniques than their male counterparts" (p. 136).

Gursoy (2013) obtained the attitudes of prospective ELT teachers towards English language. In this study, it was revealed that all the participants had mildly positive attitudes towards English but among them the female participants' attitudes were more positive than men. According to the result section of this research study "the trainees showed the highest positive attitude toward the social and instrumental value of English" (Gursoy, 2013, p. 111). The results of the study also supported the literature in terms of the relationship between attitude and success, as well as gender differences. The results indicated that ELT teacher trainees have mildly positive attitudes toward English language and around 80 percent of the participants showed that they have had little or no difficulty during their ELT education (Gursoy, 2013). In this research study, however, classroom management was obtained as the most dominant subarea of Foreign Language Teachers Beliefs Questionnaire and instructional strategies and student engagement got the second and the third place respectively.

\subsection{Applications and Implications}

Lots of studies have been carried out in the field of language teaching and learning. Different variables such as individuals, tasks, methods, etc. have been assessed and decisions have been made based on obtained results. Researchers have always searched for more incentives and perspectives both in the area of language learning and language teaching. Because many studies have been developed for the purpose of making decisions about individuals, more attention to fundamental factors in teaching and learning seem to be necessary. Therefore, some researchers have focused on the research problems the answers of which can help the community of people working in that area.

Although the role of several individual characteristics has been investigated up to now, the roles of teaching attitude and personality type seem to be less touched in some aspects. The results of the present study can guide educators and researchers to continue exploring the way personality and attitude can affect the performance of teachers and students in classroom regarding different aspects of education. Despite of its limitations, this study contributes to the growing body of literature on personality, attitude, and teaching success of English teachers in major ways. The findings of the present study are of value to all those involved in foreign language teaching, research, and education. Findings have numerous implications for research and practice in personnel psychology and would be useful for institutes' supervisors and administrators, and teacher evaluators.

Being aware about the personality type of English teachers will also be useful for material developers, teachers' colleagues, and supervisors. The present study indicates the criteria of a successful English teacher in the eyes of EFL learners which can be useful for teachers themselves. Being aware of personality and attitude differences helps employers and educational authorities to know the teachers better and to place them in positions where they will probably succeed and meet the needs of their audience. 
Ghorbani, S., Akbari, O., \& Ghonsooly, B.

\subsection{Suggestions for Further Research}

The same research can be done with more participants and a more representative sample in the same city and also other Iranian cities in order to make a wider generalization of the results. The same research can also be done among English teachers teaching at Iranian public schools as the present research study has investigated the situation just in Mashhad's private foreign language institutes. Replication of this study in public schools seems to be important, since there are some differences between teachers of private language institutes and teachers of public schools in Iran. Other researchers are also demanded to investigate the relationship between teachers' attitudes and their personalities since there may be some relations between EFL teachers' teaching attitudes and their personalities. EFL teachers' years of experience and gender have not been taken into consideration so other researchers are demanded to consider these factors in similar studies. This study can also be done by other instruments of data gathering such as interview, observation, and many others.

\section{References}

Alibakhshi, G. (2011). On the impacts of gender and personality types on Iranian EFL teachers' teaching efficacy and teaching activities preferences. Iranian Journal of Applied Linguistics, 14(1), 1-22.

Allport, G.W. (1935). Attitudes. Worcester: Clark University Press.

Azizinezhad, M., Hashemi, M., \& Darvishi, S. (2013). The relationship between EFL teachers' attitudes, teaching techniques and classroom (large and small). Procedia- Social and Behavioral Sciences, 93, 134-137. http://dx.doi.org/10.1016/j.sbspro.2013.09.165

Behnam, B., \& Bayazidi, M. (2013). The relationship between personality types and teaching styles in Iranian adult TEFL context. Global Journal of Foreign Language Teaching, 2, 21-32.

Blaskova, M., Blasko, R., Jankalova, M., \& Jankal, R. (2013). Key personality competences of university teacher: Comparison of requirements defined by teachers and/versus defined by students.

Procedia-Social and Behavioral Sciences, 114, 466-475. http://dx.doi.org/10.1016/j.sbspro.2013.12.731

Borg, S. (2006). Teacher cognition and teacher education: Research and practice. London: Continuum.

Callahan, S. G. (1966). Successful teaching in secondary schools. Chicago: Scott, Foresman.

Chacon, T. C. (2005). Teacher perceived efficacy among EFL teachers in middle schools in Venezuela. Teaching and Teacher Education, 21(3), 257-272. http://dx.doi.org/10.1016/j.tate.2005.01.001

Chastain, K. (1975). Affective and ability factors in second language acquisition. Language Learning, 25(1), 153-161. http://dx.doi.org/10.1111/j.1467-1770.1975.tb00115.x

Cook, G. (2003). Applied linguistics. Oxford: Oxford University press.

Cruickshank, D. R., Jenkins, D. B., \& Metcalf, K. K. (2003). The act of teaching. New York: McGraw-Hill.

Debreli, E. (2011). Use of diaries to investigate and track pre-service teachers' beliefs about teaching and learning English as a foreign language throughout a pre-service training program. Procedia-Social and Behavioral Sciences, 15, 60-65. http://dx.doi.org/10.1016/j.sbspro.2011.03.051

Dodge, A. F. (1948). A study of the personality traits of successful teachers. Journal of Counseling and Development, 27(2), 107-112.

Doğruer, N., Meneviş, I., \& Eyyam, R. (2010). EFL teachers' beliefs on learning English and their teaching styles. Procedia- Social and Behavioral Sciences, 3, 83-87. http://dx.doi.org/10.1016/j.sbspro.2010.07.015

Dornyei, Z. (2005). The psychology of the language learner individual differences in second language acquisition. Mahwah, New Jersey: Lawrence Erlbaum Associates, Inc.

Dornyei, Z. (2007). Research methods in applied linguistics: Quantitative, qualitative and mixed methodologies. Oxford: Oxford University press.

Ehrman, M. E. (1996). Understanding second language difficulties. Thousand Oaks, CA: Sage Publications.

Elias, J. A., \& Stewart, B. R. (1991). The effects of similarity and dissimilarity of student and teacher personality type on student grades. The Marketing Educator, 17, 42-51.

Erton, I. (2010). Relations between personality traits, language learning styles and success in foreign language 
achievement. H. U. Journal of Education, 38, 115-126.

Felder, R. M., Felder, G. N., \& Dietz, E. J. (2002). The effects of personality type on engineering student performance and attitudes. Journal of Engineering Education, 91(1), 3-17.

http://dx.doi.org/10.1002/j.2168-9830.2002.tb00667.x

Foster, R. M., \& Hornet, J. T. (1988). National profile of agricultural teacher educators and state supervisors of vocational agriculture by MBTI preference type. Journal of the American Association of Teacher Educators in Agriculture, 29(3), 20-27.

Grace, C. (1998). Personality type, tolerance of ambiguity, and vocabulary retention in CALL. The Computer Assisted Language Instruction Consortium Journal, 15(1), 19-45.

Gursoy, E. (2013). Prospective ELT teachers' attitudes toward the English language in an EFL context. Journal of International Education Research, 9(1), 107-114.

Harkin, J., \& Turner, G. (1997). Patterns of communication of styles of teachers in English 16-19 education. Research in Post-Compulsory Education, 2(3), 263-281. http://dx.doi.org/10.1080/13596749700200021

Karavas, E., \& Drossou, M. (2010). How amenable are student teacher beliefs to change? A study of EFL student teacher beliefs before and after teaching practice. In A. Psaltou-Joycey \& M. Matheoudakis (Eds.), Advances in research on language acquisition and teaching: Selected papers (pp. 261-276). Greek Applied Linguistic Association, Thessaloniki.

Lafaye, B. E., \& Tsuda, S. (2002). Attitudes toward English language learning in higher education in Japan, and the place of English in Japanese society. Intercultural Communication Studies, 11(3), 145-161.

Lamke, T. A. (1951). Personality and teaching success. The Journal of Experimental Education, 20(2), 217-259. http://dx.doi.org/10.1080/00220973.1951.11010441

Larenas, C. H. D., Moran, A. V. R., \& Rivera, K. J. P. (2011). Comparing teaching styles and personality types of EFL instructors in the public and private sectors. Profile Issues in Teachers' Professional Development, 13(1), 111-127.

Liao, P. (2007). Teachers' beliefs about teaching English to elementary school children. English Teaching and Learning, 31(1), 43-76.

Macdaid, G. P., McCaulley, M. H., \& Kainz, R. I. (1986). Myers-Briggs type indicator atlas of type tables. Gainesville, FL: Center for Applications of Psychological Type.

Mills, N. (2013). Action research: Bridging theory and practice. Academic Exchange Quarterly: Second Language Acquisition and Pedagogy, 17(1), 95-100.

Nikolov, M. (2001b). A study of unsuccessful language learners. In Z. Dörnyei \& R. Schmidt (Eds.), Motivation and second language acquisition (pp. 149-170). Honolulu, HI: The University of Hawaii, Second Language Teaching and Curriculum Center.

Pajares, M. F. (1992). Teachers' beliefs and educational research: Cleaning up a messy construct. Review of Educational Research, 62(3), 307-332. http://dx.doi.org/10.3102/00346543062003307

Pervin, L. A., \& John, O. P. (2001). Personality: Theory and research. New York: John Willy and sons.

Pishghadam, R., \& Sahebjam, S. (2012). Personality and emotional intelligence in teacher burnout. Spanish Journal of Psychology, 15(1), 227-236. http://dx.doi.org/10.5209/rev_SJOP.2012.v15.n1.37314

Pritchart, D. F. L. (1952). An investigation into the relationship between personality traits and ability in modern languages. British Journal of Educational Psychology, 22(2), 147-148. http://dx.doi.org/10.1111/j.2044-8279.1952.tb02817.x

Rahimi, M., \& Hassani, M. (2012). Attitude towards EFL textbooks as a predictor of attitude towards learning English as a foreign language. Procedia-Social and Behavioral Sciences, 31, 66-72. http://dx.doi.org/10.1016/j.sbspro.2011.12.018

Richards, J. C., \& Schmidt, R. (2002). Longman dictionary of language teaching and applied linguistics ( $3^{\mathrm{rd}}$ ed.). Harlow: Pearson Education Limited.

Rosenberg, M. J., \& Hovland, C. I. (1960). Cognitive, affective and behavioral components of attitudes. New Haven: Yale University Press.

Thomas, M. (2013). Teachers' beliefs about classroom teaching-Teachers' knowledge and teaching approaches. Procedia-Social and Behavioral Sciences, 89, 31-39. http://dx.doi.org/10.1016/j.sbspro.2013.08.805 
Ghorbani, S., Akbari, O., \& Ghonsooly, B.

Tope, O. (2011). Effects of teachers' personality on secondary school discipline: Case study of some selected schools in Nigeria. Retrieved from www.omoteretope.tk

Triandis, H. C. (1971). Attitude and attitude change. New York: Wiley.

Walker, A., Shafer, J., \& Iiams, M. (2004). "Not in my classroom": Teacher attitudes towards English language learners in the mainstream classroom. National Association for Bilingual Education Journal of Research and Practice, 2(1), 130-160.

Williams, M., \& Burden, R. (1997). Psychology for language teachers. Cambridge: Cambridge University press.

Williams, M., \& Burden, R. (1999). Students' developing conceptions of themselves as language learners.

Modern Language Journal, 83(2), 193-201. http://dx.doi.org/10.1111/0026-7902.00015

Zheng, H. (2009). A review of research on EFL pre-service teachers' beliefs and practices. Journal of Cambridge Studies, 4(1), 73-81. 